\title{
Hardships of Contact: Enamel Hypoplasias in Tupí-Mondé Amerindians From the Brazilian Amazonia
}

\author{
RICARDO V. SANTOS $1,2 *$ AND CARLOS E.A. COIMBRA J R. ${ }^{1}$ \\ 1Departamento deEndemias, Escola Nacional deSaúdePública, \\ Fundação Oswaldo Cruz, Rio deJ aneiro RJ 21041-210, Brazil \\ 2Departamento deAntropologia, Museu Nacional, \\ Rio deJ aneiro RJ 20940-040, Brazil
}

KEY WORDS dental defects; hypoplasia; Indians of Brazil; Amazonia; epidemics

\begin{abstract}
This paper presents an assessment of enamel defects (hypoplasias) in the permanent anterior teeth of three Tupi-Mondé-speaking groups from the Brazilian Amazonia: the Gavião, Suruí, and Zoró. These are native societies that experienced the onset of permanent contact with Brazilian national society in different periods of the 20th century. Tupí-M ondé dentition is highly hypoplastic, which is possibly related to exposure to adverse health and nutritional conditions. Data for the Gavião, Suruí, and Zoró are in agreement with results from other populations that show that certain teeth, the maxillary central incisors and the mandibular canines in particular, tend to be more hypoplastic. Although all types of teeth show hypoplasia concentrations at some enamel zones, there is substantial intertooth variation in the age at which peaks occur. It is argued that hypoplasia concentrations at certain ages are unlikely to be related to postweaning stresses for the Tupí-Mondé. Statistically significant associations between presence of enamel defects and deficits in physical growth (height-for-age) were detected in children 7-11 years of age. Diachronic assessment of enamel defects, which rested upon the potential of enamel as "memory" of past periods of systemic physiological perturbation, allowed us to unravel aspects related to the dynamics of Tupí-M ondé life during the 20th century. Frequencies of enamel zones with defects peaked during the contact years of each of the Tupi-Mondé groups, attesting to the extreme social and biological hardships that characterized the contact experiences of these native societies with Brazilian national society. AmJ Phys Anthropol 109:111-127, 1999. @ 1999 Wiley-Liss, Inc.
\end{abstract}

Defects of dental enamel (DDE) are developmental abnormalities that result from disturbances to ameloblasts in their enamel matrix production. Also referred to as enamel hypoplasia, there is an extensive literature in dentistry and physical anthropology that associates DDE formation with systemic physiologic perturbations during times of tooth development (Cutress and Suckling, 1982; Goodman and Rose, 1990, 1991; J ontel and Linde, 1986; Kreshover, 1960; Pindborg, 1982). According to Sarnat and Schour (1941), who pioneered the study of enamel defects, DDE might be regarded as an "accurate, prompt and permanent record" of chronol ogic development during certain periods of the individual's life. Within physical anthropology, assessment of DDE is a regu-

\footnotetext{
Grant sponsors: Brazilian Research Council (CNPq); Midwest Universities Consortium for International Activities (MUCIA).

*Correspondence to: Dr. Ricardo Santos, Departamento de Endemias/E NSP/FIOCRUZ, Escola Nacional de Saúde Pública, Fundação Oswaldo Cruz, Rua Leopoldo Bulhões 1480, Rio de J aneiro, RJ 21041-210, Brazil. E-mail: santos@ensp.fiocruz.br Received 28 September 1998; accepted 3 February 1999.
} 
lar procedure in paleopathological analyses of human skeletal samples. The same cannot besaid with regard toliving populations, among which studies of DDE are not yet as common, although some research was carried out as early as the 1930s and 1940s (Goodman and Rose, 1990, 1991). At present, there is a growing interest in epidemiologically oriented investigations of hypoplasias in samples of contemporary populations, which in part derives from recent advances in theory and methodology (Goodman and Rose, 1990, 1991). Research conducted over the past three decades focusing on these populations has further strengthened the notion that DDE formation is closely associated with the occurrence of illnesses and nutritional stresses (Enwonwu, 1973; Goodman et al., 1987, 1991, 1992; Maunders et al., 1992; May et al., 1993; Sawyer and Nwoku, 1985; Seow, 1992; Suckling and Pearce, 1984; Sweeney et al., 1969, 1971).

The aim of this paper is the assessment of enamel defects in the permanent anterior teeth of three Tupí-M ondé-speaking Amerindian groups from the Brazilian Amazonia: the Gavião, Suruí, and Zoró. These are native societies that experienced the onset of permanent contact with Brazilian national society at different moments of the 20th century. This study has three specific purposes: first, to present data on frequencies of DDE by tooth type and enamel zone as well as by ethnic group; second, to analyze the relationship between DDE and anthropometric parameters of nutritional status in children; and third, to evaluate levels of physiological perturbation experienced by Tupí-Mondé groups across time. This diachronic analysis is conducted by evaluating the temporal distribution of hypoplasias in a sample of Tupí-Mondé adults and children born between the 1920s and the 1980s. One might postulate that individuals who had their permanent teeth formed during the stressful period of contact would show an increased proportion of enamel zones with defects. Hence, drawing on the unique feature of hypoplasias as permanent and chronol ogic records of past physiological perturbations experienced by individuals during amelogenesis, assessment of DDE is utilized here as a window to gain insights into Tupí-Mondé social and biological history throughout the 20th century.

\section{THE TUPÍ-MONDÉ}

Therearefour Tupí-M ondé societies living on reservations located in theA ripuanã river basin, in the Brazilian states of Rondônia and Mato Grosso, Southwestern Amazonia (Fig. 1). This paper deals with three of them: the Gavião, Suruí, and Zoró. These are native groups that experienced the onset of permanent contact with Brazilian national society as a result of frontier expansion at different time periods: the Gavião in the 1930-1940s, the Suruí in the late 1960early 1970s, and the Zoró in the second half of the 1970s.

The Tupí-Mondé are upland forest dwellers whose traditional subsistence is based on shifting horticulture, hunting, fishing, and gathering. The Aripuanã region is rolling country, crossed by small water courses, and mostly covered by interfluvial upland forest. Traditionally, Tupí-Mondé societies are nonstratified from a socioeconomic standpoint (Coimbra, 1989; Santos, 1991; Santos and Coimbra, 1996).

The history of Tupí-Mondé peoples is poorly documented. As far as is known, travelers did not reach what is known today as the Aripuanã area in the colonial period (17-18th centuries). More recently, some effort has been made to compile ethnohistorical information. Systematic archaeological research in the Aripuanã area is yet to be carried out. Notwithstanding, recent studies have suggested that the Tupí-Mondé have long been influenced by Western expansion in the Amazon Basin (Brunelli, 1989; Coimbra, 1989; Meireles, 1984). There is evidence that they descend from groups which would have reached the forests of Rondônia and northern Mato Grosso after coming from far away, fleeing from intensified intertribal warfare associated with the arrival of Europeans centuries ago (Coi mbra, 1989).

The Aripuanã region remained relatively isolated for most of the colonial period. Although the Portuguese reached Southwestern Amazonia as early as the 18th century, the occupation was confined to the margins of the major rivers, away from Tupí-M ondé territories. Native groups living al ong those 


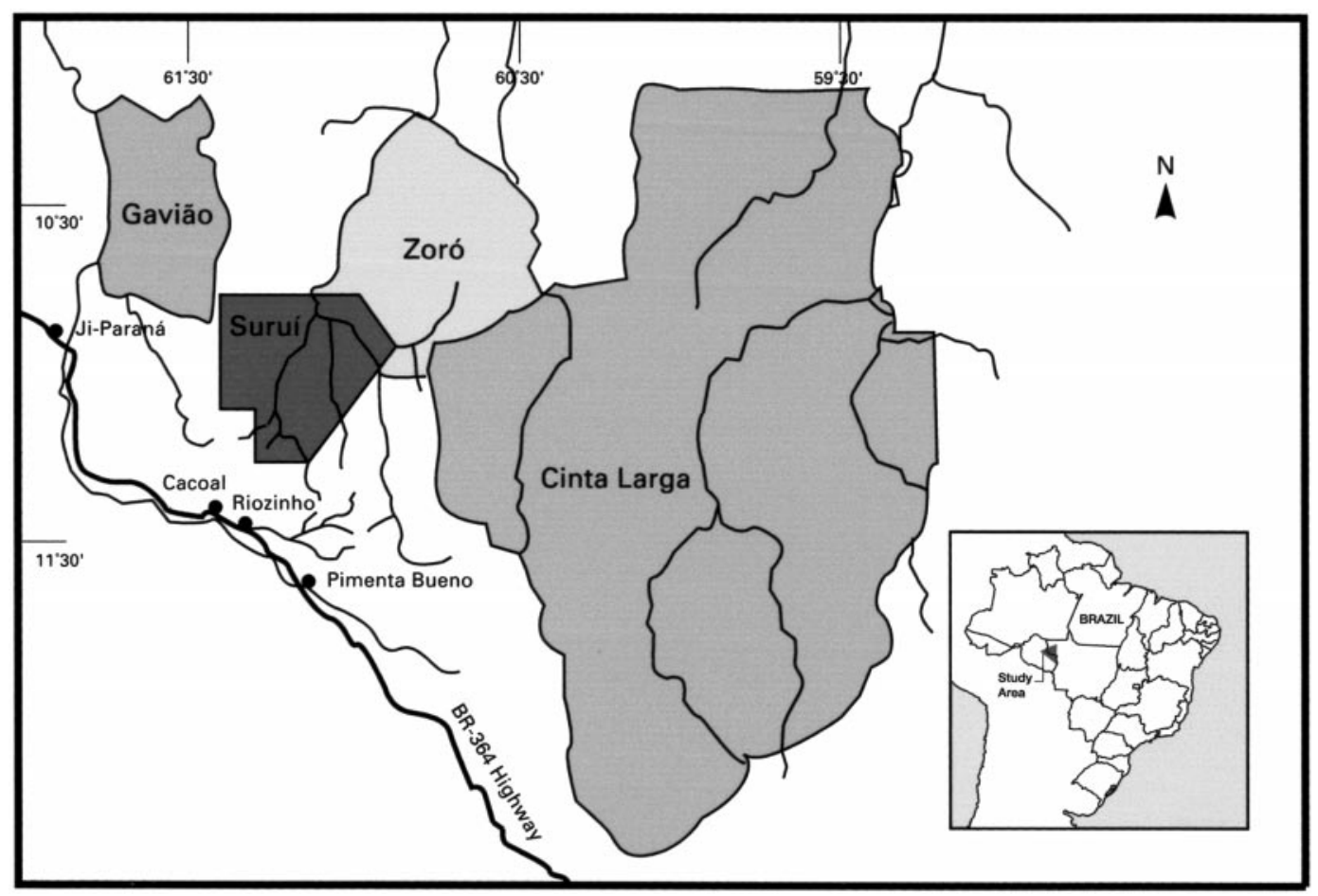

Fig. 1. Geographic location of Tupí-M ondé reservations, Brazilian Amazonia.

rivers were those which experienced the most disruptive consequences (epidemics, enslavement, and social disruption) in this early phase of European expansion into the region (Davidson, 1970; Hemming, 1987; Meireles, 1984).

The relative isolation of Tupí-Mondé groups started breaking down at the end of the 19th century. Due to the expanded demand for rubber in the world market, the frontier penetrated inland al ong the tri butaries of the large rivers (Hemming, 1987; Weinstein, 1983). During that period, the Amazon region witnessed a sudden rush of landless peasants who came to work in the extraction of natural rubber. The rubber trade and industry dominated the Amazonian regional economy, and as the frontier was pushed further inland, the isolation of native upland forest dwellers, such as the Tupí-Mondé, became threatened (Coimbra, 1989; Davidson, 1970; Meireles, 1984). Researchers have estimated that over 30 different native groups were annihilated as the rubber enterprise expanded into Southwestern Amazonia (Ribeiro, 1956).

Changes accel erated in the first half of the 20th century. Two significant events took place during this period: the construction of telegraph lines which crossed Tupí-Mondé territories, and a second rubber boom during World War II (Hemming, 1987; Ribeiro, 1956; Weinstein, 1983). Several hundred kilometers of Rondônia and Mato Grosso were crossed by expeditions which, between 1907-1914, constructed telegraph lines connecting Mato Grosso to Amazonas. The workers went deep into the forest and made firsthand contact with a number of yet isolated groups. The lines opened up large unexplored areas to Brazilian national society, resulting in the extinction of a number of native groups. With regard to the Amazonian rubber industry, it had been greatly affected in the early part of the century when large plantations were established in Malaysia by the British. The Amazonian rubber economy regained impetus during 
World War II, as supplies from Malaysia could not reach the allies because of the J apanese occupation (Santos, 1980; Weinstein, 1983). It was during this second boom that new waves of northeastern Brazilian workers arrived in Amazonia. Contact with the Gavião dates to this period (19301940s).

The second half of this century witnessed a sharp accel eration in Western penetration toward Southwestern Amazonia (Coy, 1987; Davis, 1977; Moran, 1984; Mueller, 1980). Starting in the 1960s, government efforts aimed at occupying and integrating the re gion into the Brazilian national context. National and international capital, mainly through loans provided by the World Bank, was channel ed to the region. The "development" effort resulted in the opening of highways and in the establishment of large col onization and mining projects. These were the conditions needed for the onset of the largest migratory movement in Amazonian history. Most of this growth was due to immigration in the 1970s. The huge influx of migrants changed the nature of the nearly century-long contact that local Amerindian groups had maintained with Brazilian nationals. Up to that period, the still semiisolated groups were used to fighting with rubber-tappers who periodically invaded their territories, and they could still retreat to unoccupied areas. As Rondônia and northern Mato Grosso became increasingly occupied by colonists and land squatters, several Tupí-Mondé groups, including the Suruí (in 1969) and Zoró (in 1977), were forced to come into permanent contact with Brazilian national society.

\section{HUMAN BIOLOGICAL CONSEQUENCES OF CONTACT}

Native populations from Southwestern Amazonia experienced increased mortality due to epidemics of infectious and parasitic diseases long before the establishment of permanent contact with Brazilian national society (Brunelli, 1989; Caspar, 1957; Coimbra, 1989; Conklin, 1989; Meireles, 1984; Ribeiro, 1956; Santos, 1991). This implies that European penetration impacted on native peoples well prior to the onset of permanent interaction with the regional system.
Caspar (1957), for instance, reported on a measles epidemic which broke out in the first half of this century among the Tuparí, a neighboring group of the Tupí-Mondé, and which led to the annihilation of the entire population before the establishment of permanent contact. The anthropologist Claude Lévi-Strauss, who traveled in Mato Grosso and Rondônia in the 1930s, provided in his Tristes Tropiques a compelling description of a visit to a relatively isolated Tupí settlement in theAripuanã area. He wrote:

In all there were six women, seven men, and one of them only an adolescent, and three little girls who seemed to be one, two, and three years of age; it was no doubt one of the smallest groups who could be imagined as managing to survive ... Two members of the groups were afflicted with paralysis of the lower limbs: a young woman went about on two sticks, and a man, also young, dragged himself along the ground like a legless cripple ... I wondered if poliomyelitis or some other virus had affected them, even before they had had time to establish lasting contact with civilization" (Lévi-Strauss, 1955, translated from $F$ rench).

Tupí-M ondé peoples faced massive depopulation when permanent contact was established. A succession of measles, tubercul osis, and flu epidemics in the late 1960s and in the first half of the 1970s killed close to $75 \%$ of the Suruí (Coimbra, 1989; Meireles, 1984). Chiappino (1975), a Red Cross physician who worked among the Suruí a few years after contact in 1969, reported that about $60 \%$ of the population had tuberculosis. Brunelli (1989) estimated that the Zorónumbered between 1,000-1,500 individuals distributed into several local groups in the immediate precontact period. This figure is almost five times higher than the Zoró population as of 1990. The Gavião also experienced stressful conditions by the time of the onset of their permanent contact (Meireles, 1984). Coimbra (1989) argued that, due to pronounced depopulation, the current composition of the Tupí-Mondé is a simplification of a more complex ethnic configuration which once existed in the Aripuanã.

At present, health conditions of TupíMondé peoples are precarious, reflecting structural inadequacies in food production, sanitation, and health care. The list of endemic diseases is long and includes malaria, leishmaniasis, hepatitis, tuberculosis, intestinal parasitism, skin diseases, gastroenteri- 
tis, upper respiratory infections and sexually transmitted diseases (Coimbra et al., 1985a,b, 1994, 1996a,b; Coimbra, 1989; Coimbra and M ello, 1981; Coi mbra and Santos, 1991a; Santos et al., 1991). Protein-energy malnutrition and anemia are two nutritional disorders frequent in Tupí-Mondéreservations (Coi mbra and Santos, 1991b; Santos, 1991; Santos and Coimbra, 1991). Unfortunately, there is limited demographic information on theTupí-M ondé. In an analysis of secondary data, Coimbra (1989) found that the infant mortality rate in the Suruí reached the extremely high rate of 232.2 per 1,000 in the 1980s.

The determinants of Tupí-Mondé poor health and nutrition are complex, but it seems that departure from their traditional subsistence system has worsened the situation. Due to intrinsic ecological conditions, the combination of hunting-gathering-horticulture as widely practiced by native Amazonians seems to be adaptive only under conditions of high mobility. The Tupí-M ondé have abandoned their seminomadic way of life and are now living in larger permanent settlements, resulting in greater pressure upon natural resources. The adoption of cash crops (e.g., coffee) and logging also brought about major environmental changes. Some of the consequences of these changes upon Tupí-Mondé ecology were shortened fallow, decreased agricultural and hunting/ fishing potential, and soil degradation. Reduced mobility also enhances environmental contamination. Sanitary conditions are precarious in all Tupí-Mondé villages, as none have effective sewage disposal systems. Defecation takes place in bushes close to the houses, where domestic garbage is al so thrown. These are favorable conditions for the spread of waterbornediseases, gastroenteritis in particular, which are known to be major health problems among the TupíMondé. The inadequate provision of health services further compromises the well-being of Tupí-Mondé peoples. Living in an area of frontier expansion where the transmission of several diseases is rampant, native populations of Southwestern Amazonia are offered few opportunities to cope with the situation. Lack of infrastructure and personnel aremajor constraints in the provisioning
TABLE 1. Number of teeth and individuals examined for dental enamel defects for each Tupí-Mondégroup

\begin{tabular}{|c|c|c|c|c|c|c|}
\hline & \multicolumn{2}{|c|}{ Gavião } & \multicolumn{2}{|c|}{ Suruí } & \multicolumn{2}{|c|}{ Zoró } \\
\hline & Right & Left & Right & Left & Right & Left \\
\hline \multicolumn{7}{|l|}{ Maxillary } \\
\hline Canines & 51 & 48 & 58 & 61 & 38 & 36 \\
\hline $\begin{array}{l}\text { Lateral inci- } \\
\text { sors }\end{array}$ & 50 & 53 & 68 & 63 & 52 & 48 \\
\hline $\begin{array}{l}\text { Central inci- } \\
\text { sors }\end{array}$ & 58 & 56 & 74 & 70 & 55 & 55 \\
\hline \multicolumn{7}{|l|}{ Mandibular } \\
\hline Canines & 69 & 69 & 73 & 73 & 55 & 53 \\
\hline $\begin{array}{l}\text { Lateral inci- } \\
\text { sors }\end{array}$ & 77 & 74 & 80 & 82 & 65 & 65 \\
\hline $\begin{array}{l}\text { Central inci- } \\
\text { sors }\end{array}$ & 74 & 74 & 74 & 73 & 62 & 63 \\
\hline $\begin{array}{l}\text { Total number } \\
\text { of individuals } \\
\text { and age } \\
\text { ranges }\end{array}$ & \multicolumn{2}{|c|}{$\begin{array}{c}79 \\
6-64 \text { years }\end{array}$} & \multicolumn{2}{|c|}{$\begin{array}{c}87 \\
6-66 \text { years }\end{array}$} & \multicolumn{2}{|c|}{$\begin{array}{c}65 \\
7-62 \text { years }\end{array}$} \\
\hline
\end{tabular}

of adequate health services. Vaccination is often behind schedule and the long-term treatment of some diseases, including tuberculosis, is seldom properly provided (Coimbra, 1989; Santos, 1991).

\section{METHODS General procedures}

This study closely follows the methodology described in Goodman et al. (1987), which involved recording enamel defects on the buccal side of the superior and inferior anterior dentition (left and right canines, lateral incisors, and central incisors), totaling 12 teeth. Anterior teeth were chosen because they are the easiest to examine under field conditions, apart from presenting relatively high defect rates compared to posteri or teeth (Cutress and Suckling, 1982; Goodman and Armelagos, 1985; Goodman and Rose, 1990, 1991; King and Wei, 1992). Only permanent teeth were considered for the purpose of this study. DDE were not recorded on the deciduous teeth of children with mixed dentition.

The sample included 79 Gavião, 87 Suruí, and 65 Zoró, totaling 231 individuals. Ages ranged from 6-66 years (Table 1 ). This range is justifiable by one of the aims of this study: to compare prevalences of hypoplasias across time. No specific sampling procedure was utilized. The sample was composed of individuals willing to partici pate in the study.

The classification of defects utilized followed the recommendations of the Fédéra- 
tion Dentaire Internationale (FDI)(1982). Three types of defects were recorded: 1) linear enamel hypoplasia (LEH) or hypoplastic horizontal grooves (FDI type 4); 2) hypoplastic pits (HP) or pitting hypoplasias (FDI type 3); and 3) missing enamel (ME) (FDI type 6). Neither opacities nor discolored enamel were recorded, since they have been shown to be less likely the result of physiological disruption (Goodman and Rose, 1990, 1991; Goodman et al., 1987). Following Goodman et al. (1987), DDE types 4 and 6 were combined. Hence this study reports on two classes of defects: 1) linear hypoplasia (LEH) and missing enamel (ME), and 2) hypoplastic pits (HP).

Enamel defects were recorded by type on a diagram in which the 12 teeth were represented. Enamel defects were recorded on the drawing so as to reflect their size, number, and location on the tooth surface. Missing teeth, areas of incomplete eruption, and missing enamel zones due to attrition were al so noted on the diagram.

Based on the standard of enamel crown devel opment of Massler et al. (1941), Goodman et al. (1987) detailed a methodology for estimating individuals' age at time of defect formation (see also Goodman and Rose, 1990, 1991; Goodman et al., 1991). The procedure involves dividing tooth crowns into equalwidth transverse zones from the most incisal to the most gingival region. For the purpose of this investigation, canines were divided into six zones corresponding to 1.0year-long developmental intervals, maxillary lateral incisors into seven (0.5-yearlong intervals), maxillary central incisors into nine (0.5-year-long intervals), and mandibular lateral and central incisors into eight (0.5-year-long intervals) (see the first columns of Tables 4 and 5 for chronology). A transparency depicting the diagram with each tooth divided into the various zones aided in data recording. It is of note at this point that, in estimating time periods of enamel formation, we are relying on the assumption that rates of enamel development are constant, regardless of tooth and crown zone (Goodman and Rose, 1990, 1991), and that the standard of Massler et al. (1941) is appropriate for a specific set of populations such as the Tupí-M ondé.
The field recording of DDE was undertaken in summer, 1990 (Gavião and Suruí) and in summer, 1991 (Zoró). All data were collected by a single observer (R.V.S.). In order to assess intraobserver variation in DDE scoring, data on 10 individuals were scored twice in summer, 1991.

\section{Procedures in the diachronic analysis}

In order to verify temporal variations in frequencies of enamel defects, a first step was to estimate the time period (year) when enamel zones were formed. To this end we also relied on the chronology put forward by Massler et al. (1941), which provides information concerning the age at initiation and at ending of enamel matrix formation for each tooth type. For example, enamel crown formation of the permanent maxillary lateral incisors is estimated to take place between age 1-4.5 years, and of the permanent mandibular canines between age 0.5-6.5 years (see chart depicting chronology in Goodman et al., 1980). Therefore, a 60-yearold Tupí-Mondé subject (as of 1990) had the crown formation of maxillary lateral incisors and mandibular canines mostly in the first half of the 1930s, i.e., approximately between 1931-1935 and 1930-1936, respectively. This rationale was followed in order to estimate when each enamel zone was formed and, subsequently, to compute the proportions of zones with defects according to time periods. Sometimes teeth of a given individual provided information on DDE frequencies for more than one decade. For instance, crown formation of the mandibular incisors is estimated to begin at birth and to end at age 4 years. This 48-month period in an individual who was 32 years old in 1990 (thus born in 1958) took place approximately between 1958-1962. Again, we should mention that we are relying on the assumption that rates of enamel development are constant, regardless of tooth and crown zone (Goodman and Rose 1990, 1991).

Results from the diachronic analysis are presented in 10-year periods. This pooling of data was necessary because years of birth of Tupí-Mondé adults are not known with precision. In addition, sample sizes would be very reduced for time intervals shorter than 10 years. For earlier periods (before the 
1950s), findings had to be pooled, since the number of individuals older than age 40 years presenting most of the anterior teeth was rather small. It should also be noted that the available data did not allow for projections beyond the 1920s for any of the groups. A longer time span would require a sample of individuals age 70 and older with sufficient dentition, which is not available.

Not all transverse enamel zones were considered for the purpose of the diachronic analysis. Teeth of Tupí-M ondé adults sometimes present severe wear. If all enamel zones were to be included in the analysis, those closer to the incisal border in young individuals, not yet much affected by attrition, would be overrepresented in the sample, while those in older individuals would be underrepresented. Several authors found that not all enamel regions are equally susceptibleto defects (Goodman and Armelagos, 1985; Goodman and Rose, 1990, 1991; Goodman et al., 1987). To overcome this potential bias, only those transverse zones located in the middle third and in the most gingival third of each tooth were considered for the purpose of the diachronic analysis.

\section{Statistical analyses}

Statistical analyses of the prevalence and chronol ogical distribution of enamel defects, as well as associations between defects and anthropometric measurements, were performed using the SPSS-PC program (Statistical Package for the Social Sciences, 1992). A computer routine written for theSPSS-PC program was used to estimate period of formation of enamel zones of each subject and, subsequently, to determine the proportion of enamel zones affected by defects according to time periods.

\section{RESULTS \\ Intraobserver variation}

Enamel defects from 109 teeth, corre sponding to 10 individuals, were considered in the reliability study. Ninety-eight percent of the teeth were found to be hypoplastic during the first and second sets of observations (e.g., sets I and II). All teeth presenting defects in set I were also classified as hypoplastic in set II, an agreement on the order of $100 \%$. A total of 163 and 161 defects was recorded in sets I and II, respectively. One hundred and thirty-nine of the defects identified in the first group were also observed in the second group, i.e., an agreement of $85.8 \%$. This level of agreement is comparable to what was reported by other authors who conducted similar studies (Goodman et al., 1987).

In order to more closely evaluate intraobserver variation in the identification of defects by enamel zones, we chose to compare frequencies of defects for the mandibular and maxillary central incisors. These tooth types were selected because they are divided into the greatest number of zones (i.e., eight and nine). The 10 pairs of observations (sets $A$ and B) included 40 teeth and 340 enamel zones each. In set $A$, 58 zones were detected with defects, and in set B, 57 zones. Fiftyone zones were recorded as presenting defects in both sets. Thus, seven zones with defects recorded in set $A$ were not recorded in set $B$, while six zones with defects in $B$ were not recorded with defects in set $A$. In set $A, 67$ defects were detected, and in set $B$, 59, totaling 126 defects. Forty-nine were pairs of defects recorded approximately in the same location on the tooth surface: 41 in the very same enamel zone, and eight in an immediately neighboring zone (e.g., considering that the maxillary central incisors are divided into nine zones, by "immediately neighboring zones" we mean the second and third zones or the fifth and sixth). These findings suggest a high level of intraobserver agreement: $73.1 \%(49 / 67)$ and $83.1 \%$ $(49 / 59)$ of the defects observed in sets $A$ and $B$, respectively, were detected in the very same zone or in an immediatel y neighboring zone of the other set. When frequency distributions of zones with defects in sets A and B were compared (similar to data presented in Tables 4 and 5), curves with peaks of hypoplasia concentrations at comparable ages were obtained.

\section{Frequencies of DDE}

Hypoplastic defects are almost universal for the Tupí-M ondé: $96.2 \%$ of the Gavião and $100 \%$ of the Suruí and of the Zoró presented at least one defect in their anterior dentition, totaling $98.7 \%$ for the three groups. 
TABLE 2. Frequencies (\%) of teeth with at least oneenamel defect and total samplesizes ${ }^{1}$

\begin{tabular}{lccc}
\hline & Right & Left & Both \\
\hline Maxillary & & & \\
$\quad$ Canines & $76.5 \%(\mathrm{n}=85)$ & $76.2 \%(\mathrm{n}=80)$ & $76.4 \%(\mathrm{n}=165)$ \\
$\quad$ Lateral incisors & $77.9 \%(\mathrm{n}=104)$ & $74.3 \%(\mathrm{n}=105)$ & $76.1 \%(\mathrm{n}=209)$ \\
$\quad$ Central incisors & $88.1 \%(\mathrm{n}=126)$ & $87.8 \%(\mathrm{n}=123)$ & $88.0 \%(\mathrm{n}=249)$ \\
Mandibular & $81.0 \%(\mathrm{n}=116)$ & $73.8 \%(\mathrm{n}=107)$ & $77.6 \%(\mathrm{n}=223)$ \\
$\quad$ Canines & $73.3 \%(\mathrm{n}=135)$ & $74.8 \%(\mathrm{n}=131)$ & $74.1 \%(\mathrm{n}=266)$ \\
Lateral incisors & $76.8 \%(\mathrm{n}=138)$ & $68.9 \%(\mathrm{n}=135)$ & $72.9 \%(\mathrm{n}=273)$ \\
Central incisors & &
\end{tabular}

${ }^{1}$ Data are for Gavião, Suruí, and Zoró males and females of all ages. Only teeth with all enamel zones present are included.

Table 2 presents data on frequencies of teeth with at least one DDE. These results refer only to teeth with all enamel zones present. We opted to exclude those teeth showing attrition or not fully erupted because one could not evaluate missing transversal zones. Out of 1,385 teeth with all enamel zones present, 1,073 (77.5\%) were hypoplastic.

The frequencies of enamel defects greatly varied by individual tooth types (Table 2). Maxillary central incisors and mandibular canines were those most affected by hypoplasias, while mandibular central and lateral incisors were the least affected. Rates tended to decrease anteriorposteriorly in the maxillary dentition and posterioranteriorly in the mandibular dentition. Prevalences were a little higher in maxillary teeth (ranging from $76.1 \%$ for lateral incisors to $88.0 \%$ for central incisors) than in mandibular teeth (ranging from $72.9 \%$ for central incisors to $77.6 \%$ for canines). Overall, antimeres tended to be equally affected by defects: the lowest discrepancy was for maxillary canines $(76.5 \%$ vs. $76.2 \%)$ and for maxillary central incisors ( $88.1 \%$ vs. $87.8 \%$ ); the highest was for mandibular central incisors (76.8\% vs. $68.9 \%$ ).

Linear enamel hypoplasia (LEH) and missing enamel (ME) were more common in Tupí-Mondé teeth than were hypoplastic pits (HP) (Table 3 ). There was also a greater variation in percentage of zones affected with LEH and ME compared to HP. The right mandibular central incisors (10.6\%) and the right maxillary canines $(24.1 \%)$ were, respectively, the teeth with the lowest and the highest proportion of enamel zones affected by LEH and ME. For HP, the left mandibular canines (6.7\%) and theleft max- illary canines and right maxillary central incisors (both with $8.5 \%$ ) presented, respectively, the lowest and highest rates.

Although DDE wereobservable in all zones of the canines, lateral incisors, and central incisors, frequencies greatly varied from zone to zone and from tooth to tooth (Tables 4, 5). The highest frequency $(57.2 \%)$ was found in the third zone of the right maxillary central incisor, and the lowest $(0 \%)$ in the ninth zone of the left maxillary central incisor.

$\mathrm{H}$ ypoplastic defects were more common in certain enamel zones (Tables 4, 5). Those most incisal and those most gingival showed the lowest frequencies of defects. Although we observed hypoplasia concentrations in all tooth types and in most enamel zones, individuals' age at time of physiological disruption varied from tooth to tooth. Most teeth showed an increase in frequencies of defects in those zones corresponding to ages at development of 3 and 4 years (maxillary lateral and central incisors) or 3 and 5 years (maxillary and mandibular canines). Only the mandibular lateral and central incisors displayed peaks at ages 2 and 3 years.

\section{Sex differences}

Males and females differed little in DDE frequencies. Chi-square tests were performed in order to evaluate whether frequencies of DDE differed between sexes. Comparisons were made for each of the 44 maxillary and mandibular enamel zones. The null hypothesis of no difference was rejected in only four of the 88 tests performed $(P \leq$ 0.05 ). When differences were detected, males and females showed higher frequencies in two comparisons each. 


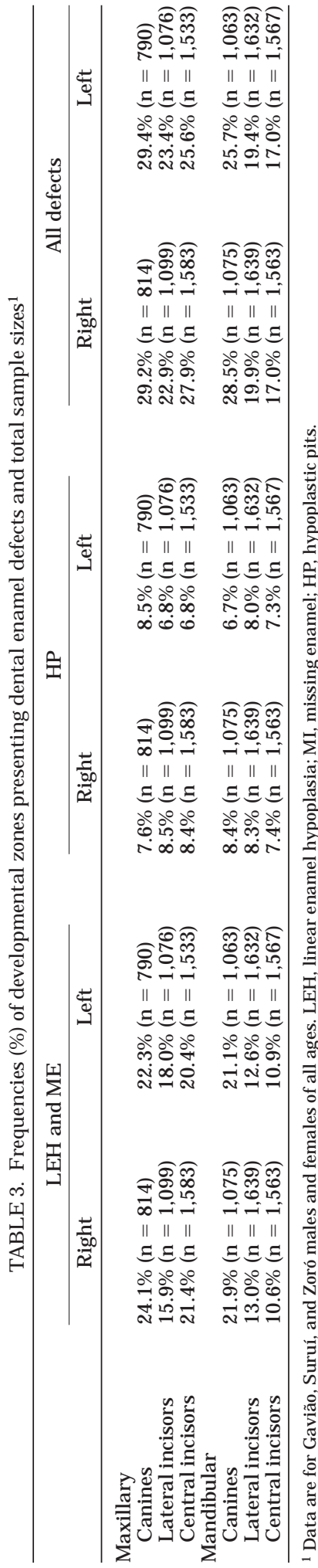

TABLE 4. Total number of devel opmental zones
and frequencies (\%) of dental enamel defects
for themaxillary permanent anterior teeth ${ }^{1}$

\section{DDE and height for age in Tupí-Mondé children}

A sample of 68 (35 boys and 33 girls) 7-11-year-old Tupí-Mondé children was divided into two groups. The first group included subjects with height-for-age z-score values equal to or below -1.5 standard deviations (SD) from National Center for Health Statistics (NCHS) mean values, and 
TABLE 5. Total number of devel opmental zones and frequencies (\%) of dental enamel defects for the mandibular permanent anterior teeth ${ }^{1}$

\begin{tabular}{|c|c|c|c|c|}
\hline & \multicolumn{2}{|c|}{ Right } & \multicolumn{2}{|c|}{ Left } \\
\hline & $\begin{array}{l}\text { Sample } \\
\text { size }\end{array}$ & $\begin{array}{l}\% \text { with } \\
\text { defects }\end{array}$ & $\begin{array}{l}\text { Sample } \\
\text { size }\end{array}$ & $\begin{array}{l}\% \text { with } \\
\text { defects }\end{array}$ \\
\hline \multicolumn{5}{|l|}{ Canines } \\
\hline $\begin{array}{l}\text { 1st zone, } \\
0.5-1.5 \text { yrs }\end{array}$ & 124 & 3.2 & 118 & 1.7 \\
\hline $\begin{array}{l}\text { 2nd zone, } \\
1.5-2.5 \mathrm{yrs}\end{array}$ & 180 & 18.9 & 178 & 124 \\
\hline 3rd zone, & & & & \\
\hline $\begin{array}{l}2.5-3.5 \text { yrs } \\
\text { 4th zone }\end{array}$ & 196 & 27.0 & 195 & 28.2 \\
\hline $3.5-4.5$ yrs & 195 & 44.6 & 194 & 41.8 \\
\hline $\begin{array}{l}\text { 5th zone, } \\
4.5-5.5 \mathrm{yrs}\end{array}$ & 190 & 516 & 189 & 476 \\
\hline 6th zone, & & & & \\
\hline $\begin{array}{r}5.5-6.5 \mathrm{yrs} \\
\text { Lateral incisors }\end{array}$ & 190 & 15.8 & 189 & 12.2 \\
\hline 1st zone, & & & & \\
\hline $0.0-0.5 \mathrm{yrs}$ & 135 & 1.5 & 132 & 0.8 \\
\hline $\begin{array}{l}\text { 2nd zone, } \\
0.5-1.0 \text { yrs }\end{array}$ & 184 & 6.5 & 186 & 4.3 \\
\hline $\begin{array}{l}3 \text { rd zone, } \\
1.0-1.5 \text { yrs }\end{array}$ & 213 & 20 & 209 & 139 \\
\hline 4th zone, & & 20.2 & 209 & 10.9 \\
\hline $\begin{array}{l}1.5-2.0 \mathrm{yrs} \\
5 \mathrm{th}\end{array}$ & 220 & 27.7 & 221 & 24.9 \\
\hline $2.0-2.5$ yrs & 222 & 31.5 & 221 & 36.7 \\
\hline $\begin{array}{l}\text { 6th zone, } \\
2.5-3.0 \text { yrs }\end{array}$ & 222 & 37.4 & 221 & 38.5 \\
\hline $\begin{array}{l}\text { 7th zone, } \\
3.0-3.5 \text { yrs }\end{array}$ & 222 & 24.3 & 221 & 24.4 \\
\hline 8th zone, & & & & \\
\hline $\begin{array}{c}\text { 3.5-4.0 yrs } \\
\text { Central incisors }\end{array}$ & 221 & 0.5 & 221 & 1.8 \\
\hline $\begin{array}{l}\text { 1st zone, } \\
0.0-0.5 \mathrm{yrs}\end{array}$ & 138 & 0.7 & 135 & 0.7 \\
\hline 2nd zone, & & & & \\
\hline $\begin{array}{l}0.5-1.0 \text { yrs } \\
\text { 3rd zone }\end{array}$ & 175 & 2.3 & 180 & 6.7 \\
\hline $\begin{array}{l}1.0-1.5 \text { yrs } \\
\text { 4th zone. }\end{array}$ & 202 & 12.4 & 203 & 9.9 \\
\hline $1.5-2.0$ yrs & 208 & 18.8 & 209 & 20.1 \\
\hline $\begin{array}{l}\text { 5th zone, } \\
2.0-2.5 \mathrm{yrs}\end{array}$ & 210 & 286 & 210 & 240 \\
\hline 6th zone, & & & & \\
\hline $2.5-3.0$ yrs & 210 & 35.2 & 210 & 31.9 \\
\hline $\begin{array}{l}\text { 7th zone, } \\
3.0-3.5 \text { yrs }\end{array}$ & 210 & 26.7 & 210 & 31.9 \\
\hline $\begin{array}{l}\text { 8th zone, } \\
3.5-4.0 \text { yrs }\end{array}$ & 210 & 3.3 & 210 & 2.4 \\
\hline
\end{tabular}

${ }^{1}$ Data are of Gavião, Suruí, and Zoró males and females of all ages. Yrs, years.

the other included those with values above -1.5 SD (cross-sectional data). This cutoff point was chosen because it was close to the mean value of the height-for-age distribution for this sample (-1.51 SD). Since sample sizes for each sex were small and boys and girls differed little in mean age (9.00 vs. 8.73 years) and in mean z-score values $(-1.48$ vs. $-1.55 \mathrm{SD})$, results are presented for sexes combined.
Figure 2 shows percentages of enamel zones with defects for each tooth type (antimeres combined) for the two groups of TupíMondé children. For all teeth, children below -1.5 SD for height-for-age consistently showed higher percentages of enamel zones with defects. Statistically significant differences $(P \leq 0.05)$ were detected for the maxillary and mandibular central incisors and the mandibular lateral incisors. The difference was also statistically significant when one compared enamel zones of all teeth combined $(P=0.03)$.

\section{Diachronic analysis of DDE}

Tupí-Mondé group-specific DDE frequencies according to time periods (decades) of enamel formation are shown in Table 6 and in Figure 3.

All three groups showed statistically significant variations in DDE frequencies in the time span from the 1920-1950s to the 1980s (Table 6). For the Gavião, frequencies were the highest in the 1920-1950s. Rates dropped in the 1960s and 1970s, increasing somewhat in the 1980s. Zoró data showed a well-defined peak in the 1970s. Rates in the 1920-1950s and 1980s were comparable, and the lowest frequency was seen in the 1960s. For the Suruí, frequencies of DDE were the highest in the 1970s. Compared to the Gavião and Zoró, the Suruí showed less variation in DDE frequencies across time (Fig. 3).

\section{DISCUSSION}

Enamel defects are highly common in Gavião, Suruí, and Zoró dentition: nearly $100 \%$ of the individuals had one or more hypoplasias in their anterior permanent teeth. As this is the first study to record enamel defects in a sample of Amazonian Amerindian populations, comparative information at the regional level is not available. Direct comparison of Tupí-Mondé results with those of other studies is not possible dueto methodol ogical differences. Nevertheless, it is informative to briefly mention some findings for other populations. Suckling and Pearce (1984) found that less that $10 \%$ of a sample of New Zealand children displayed hypoplasias in their permanent dentition, while Downer et al. (1994) ob- 


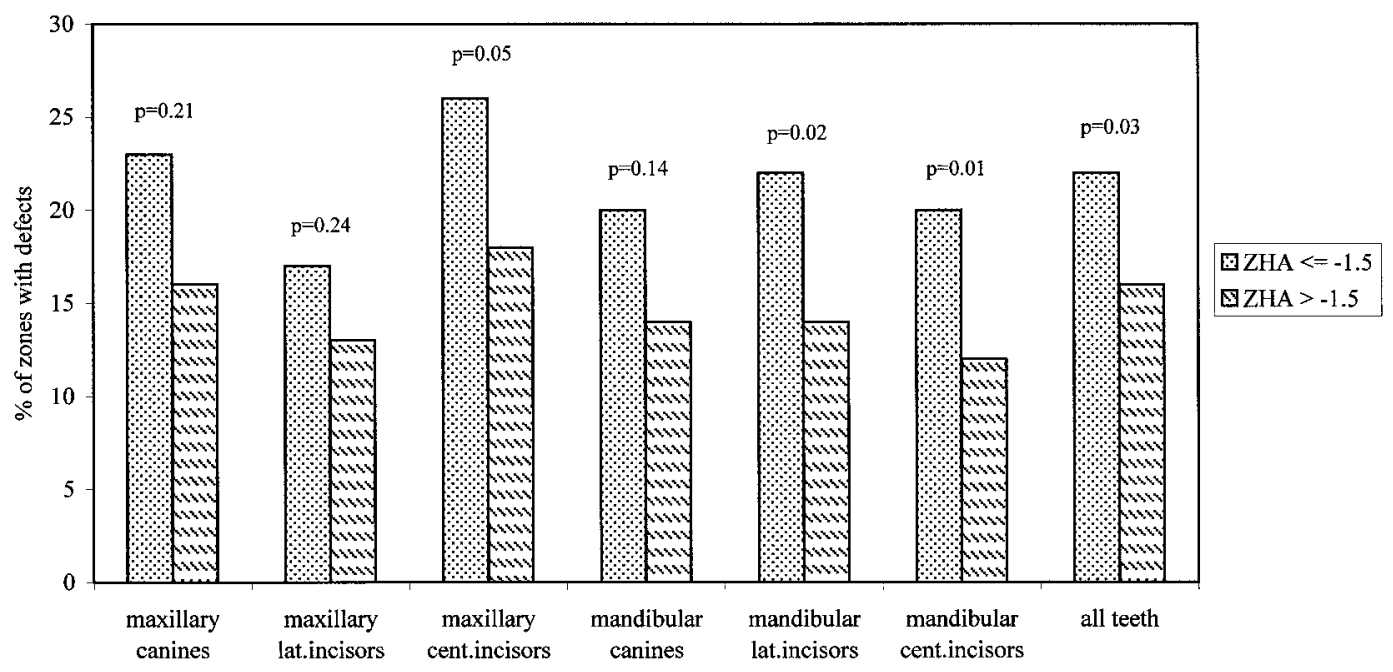

Fig. 2. Percentages of transverse zones affected by enamel defects in Tupí-M ondé children, 7-11 years old, of both sexes according to intervals of height-for-age z-scores and tooth type.

TABLE 6. Frequencies of enamel zones affected by defects for Tupí-M ondé groups according to decades of enamel formation

\begin{tabular}{llll}
\hline Decades & \multicolumn{1}{c}{ Gavião } & \multicolumn{1}{c}{ Suruí } & \multicolumn{1}{c}{ Zoró } \\
\hline $1920-1950 \mathrm{~s}$ & $35.1 \%(\mathrm{n}=462)$ & $37.3 \%(\mathrm{n}=950)$ & $30.4 \%(\mathrm{n}=207)$ \\
$1960 \mathrm{~s}$ & $27.9 \%(\mathrm{n}=524)$ & $34.0 \%(\mathrm{n}=606)$ & $22.5 \%(\mathrm{n}=413)$ \\
$1970 \mathrm{~s}$ & $20.3 \%(\mathrm{n}=905)$ & $39.3 \%(\mathrm{n}=606)$ & $36.2 \%(\mathrm{n}=789)$ \\
$1980 \mathrm{~s}$ & $22.9 \%(\mathrm{n}=1,298)$ & $31.1 \%(\mathrm{n}=1,551)$ & $29.2 \%(\mathrm{n}=1,319)$ \\
& $\chi^{2}=41.0$ & $\chi^{2}=17.4$ & $\chi^{2}=25.8$ \\
& 3 d.f. & 3 d.f. & 3 d.f. \\
& $\mathrm{P}=0.00$ & $\mathrm{P}=0.00$ & 0.00 \\
\hline
\end{tabular}

tained rates below $15 \%$ for children from Great Britain. Working in Central America, Goodman et al. (1987) found that $46.7 \%$ of mild to moderately malnourished Mexican children displayed one or more hypoplastic defects. In another study in Mexico, Goodman et al. (1991) observed that the proportion of individuals with hypoplasias could reach as much as three fourths of the sample (74.4\%). Very high rates of DDE were re ported in some paleopathological investigations that dealt with biologically highly stressed populations. These included skeletons of inhabitants of an 18th-century frontier settlement of the Northeastern United States (Wood, 1996), a 19th-century New York State poorhouse (Lanphear, 1990), enslaved 19th-century African-Americans (Blakey et al., 1994; Rathbun, 1987), and 17-19th-century Caribbean slaves (Corruccini et al., 1985). Rates of enamel defects in these populations often exceeded $70 \%$, in some cases reaching $100 \%$.

High frequencies of DDE in Tupí-Mondé dentition are expected, considering the overall adverse health and nutritional conditions to which these populations have been exposed over past decades. As mentioned before, the Tupí-Mondé have been facing biologically and socially stressful conditions for quite some time. Before and during the onset of permanent contact with Brazilian national society, epidemics of infectious diseases wiped out entire lineages and brought about a drastic population decline. At present, the Tupí-Mondé continue to be afflicted by a number of endemic infectious and parasitic diseases as well as undernutrition, particularly in children. Their subsistence system has also been negatively affected by the contact experience. It is reasonable to argue that the highly hypoplastic dentition 


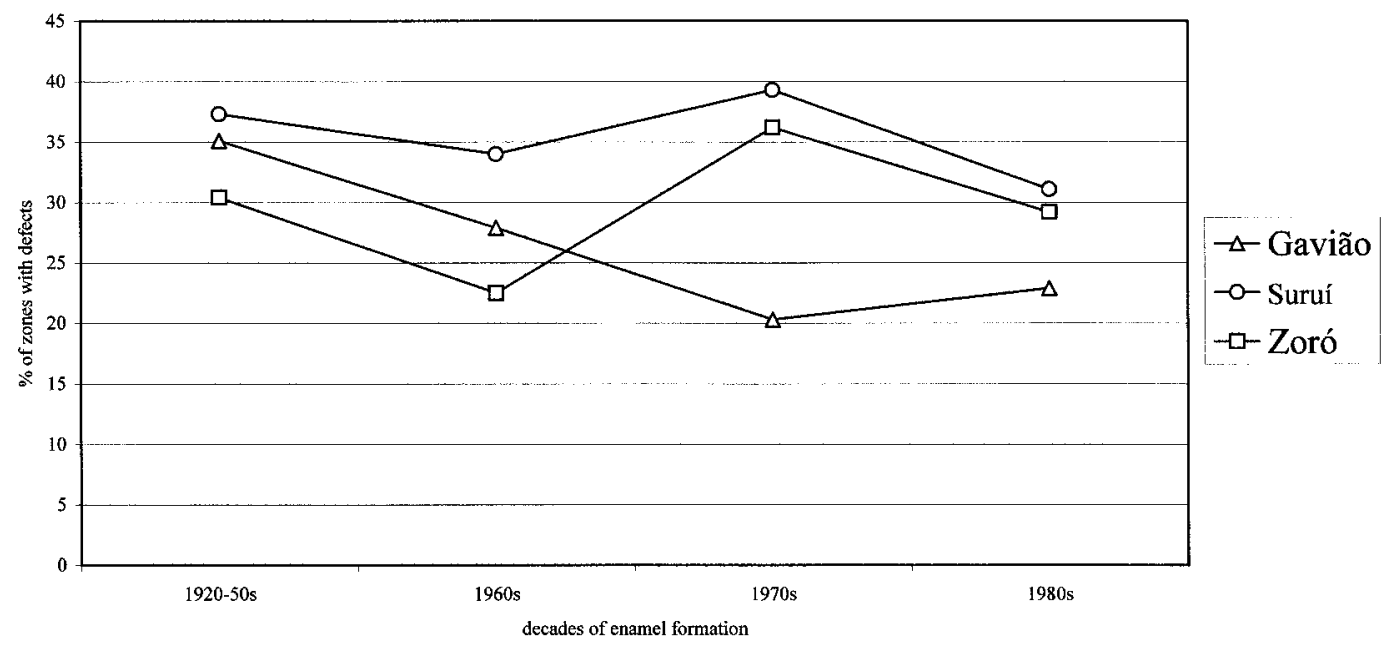

Fig. 3. Temporal variation in frequencies of enamel zones affected with defects according to Tupí-Mondé group.

of Gavião, Suruí, and Zoró children and adults is related to exposure to a plethora of environmental insults capable of bringing about pronounced levels of physiol ogical disruption in enamel-matrix apposition.

Reviews in the literature indicatesubstantial differences in the prevalence of DDE among different tooth types (Cutress and Suckling, 1982; Goodman and Rose, 1990; King and Wei, 1992). This finding has been interpreted as resulting from differences in time of crown formation as well as in sensitivity to physiological disruption (Goodman and Armelagos, 1985). Maxillary central incisors and mandibular canines are among the teeth most affected by defects. TupíMondé results conform to this pattern insofar as susceptibility to disruption greatly varies from tooth to tooth, and the maxillary central incisors and the mandibular canines are generally the most hypoplastic.

A growing number of epidemi ol ogical studies are reinforcing the relation between occurrence of enamel defects, on the one hand, and undernutrition and morbidity on the other (Enwonwu, 1973; Goodman et al., 1987, 1991, 1992; Maunders et al., 1992; May et al., 1993; Sawyer and Nwoku, 1985; Seow, 1992; Suckling and Pearce, 1984; Sweeney et al., 1969, 1971). Perhaps the most detailed study on this matter conducted so far is the one by Goodman et al.
(1991), who explored the relation between nutritional intake at the time of enamel development and subsequent presence of enamel defects. They compared two samples of Mexican adolescents (one comprising subjects who had received nutritional supplementation during childhood and an untreated control group) and found that the risk of developing an enamel defect was nearly twice as great in the nonsupplemented children. It was also detected that individuals with enamel defects had experienced in their childhood lower rates of physical growth velocity and slightly greater frequencies of days ill with gastrointestinal and upper-respiratory infections. Results for Tupí-Mondé children are in agreement with the literature, as they suggest that enamel hypoplasia correlates with anthropometric indicators of nutritional status. It was found that children that are smaller in size for their age (low height for age) present a higher proportion of enamel zones with defects (Fig. 2).

For the Tupí-Mondé, all types of teeth showed hypoplasia concentrations, although there were variations in the ages at which peaks were achieved. Most of the teeth displayed a greater proportion of affected zones corresponding to defects forming around age 3-5 years. According to a number of authors, age-related patterns in the 
frequency distribution of defects are associated with increased morbidity due to postweaning stresses (Corruccini et al., 1985; Goodman et al., 1987, 1991; Lanphear, 1990; Moggi-Cecchi et al., 1994). Blakey et al. (1994) and Wood (1996) are among those whose findings do not support this hypothesis.

There are limited data on Tupí-Mondé infant feeding practices, including quantitative information on length of breast-feeding and timing of the introduction of new food items. These would be the most appropriate kinds of information to clarify links between concentration of hypoplasias at certain ages vis-à-vis weaning. One important point to be made, however, is that weaning in TupíMondé societies is not a well-defined event in time as one sees in several other societies. In his study of the Suruí, Coimbra (1989) observed that children are exclusively fed on their mother's milk only for a relatively short period of time. However, it is not uncommon to see children as old as 3 years still suckling their mother's breasts. While still breast-feeding, but al ready ableto grasp, i.e., within a few months after birth, infants may be given other food items, both solid and premasticated. These include honey, small pieces of meat, and premasticated Brazil nuts, among many others: i.e., very early in life, Tupí-Mondé children are exposed to food-borne microorganisms, and this takes place well before full weaning takes place.

Data from anthropometric surveys suggest that Suruí children between age 1-2 years are particularly prone to undernutrition. Coimbra and Santos (1991b) found that, while $9.5 \%$ of a sample of Suruí children younger than age 1 year were bel ow -2 standard deviations from NCHS medians for weight-for-height, the rate increased to nearly $45 \%$ in children between 1-2 years. Frequencies of low weight-for-height were much lower in children between age 2-5 years (ranging from 0-6.7\%). The weight-forheight ratio is considered to be an indicator of acute undernutrition. Therefore, the combined evidence provided by ethnographic and anthropometric information does not seem to support the hypothesis that hypoplasia concentrations in Tupí-M ondé dentition, which were mostly found for enamel zones corresponding to defects forming between 3-5 years, are due to the negative biological effects of postweaning stresses.

Possibly the most interesting finding of this study comes from the diachronic analysis of DDE frequencies. Increased prevalences of enamel defects coincide in time with the periods when each Tupí-Mondé group experienced permanent contact with Brazilian national society. While the contact of the Gavião dates to an earlier part of this century (1930-1940s), permanent contact of theSuruí and the Zorótook place as recently as in the late 1960-early 1970s and in the second half of the 1970s, respectively (see Fig. 3). It is in all likelihood possible that DDE peaks for each Tupí-Mondé group are related to the devastating biological and social impacts they experienced at the time of contact. The disruptive nature of the contact experience of Amazonian native populations with national societies is welldescribed in the anthropological and human biological literature (Coimbra, 1987, 1989; Conklin, 1989; Davis, 1977; Early and Peters, 1990; Hemming, 1987; Neel et al., 1970; Ribeiro, 1956). In addition to causing high mortality, epidemics deeply affect social organization and daily life functioning. With most individuals too weak to engage in food gathering and preparation, conditions faced by survivors are highly stressful. We have already pointed out that the TupíMondé were struck by epidemics during and after contact, which came along with profound biological and social disruption. Estimates indicate that nearly half of the Suruí died in the time period when permanent contact took place (Chiappino, 1975; Coimbra, 1989). According to Brunelli (1989), the Zoró population experienced a 5-7-fold decrease from the 1960s to the late 1970s. Meireles (1984) wrote that the first years of Gavião contact with rubber-tappers were critical, as the Indians were forced to abandon their villages and subsistence practices.

It is possible that the peaks for hypoplasia concentrations for the Tupí-M ondé underestimate the actual stress load experienced by these native groups at the time of contact. Obviously, in this study only enamel defects from survivors were recorded. High mortal- 
ity might have acted as a strong filter, eliminating from the population those individuals mostly severely stressed during their childhood. Possibly, these individuals were also those who had more hypoplasias. In other words, the magnitude of peak frequencies of enamel defects could be even more pronounced if we could control for the selective action of differential mortality.

The assessment of Tupí-Mondé enamel defects also bears upon the long-term consequences of permanent contact of native peoples with the complex socioeconomic systems of national societies. A commonly held view is that "unacculturated" traditional societies are well-adapted to their environments, enjoying adequate health and nutrition. According to this line of reasoning, this well-being results from a combination of geographic isolation, nomadic or seminomadic lifestyle, knowledge of the envi ronment, subsistence practices, and dietary diversity. Changes brought about by interethnic contact would lead to the disruption of traditional subsistence practices, resulting in deprived health and nutritional conditions (Wirsing, 1985; see Dennett and Connell, 1988, for an alternative perspective).

The findings of this investigation indicate that such a dichotomous view is at best an oversimplification for the Tupí-Mondé. The diachronic analysis suggests that pre and postcontact frequencies of DDE might be of similar magnitude (see Fig. 3), i.e., the overall stress loads affecting the Tupí-Mondé in chronological periods corresponding to before and after contact are comparable in some cases. It is unlikely that, at least since the turn of this century, native populations from Southwestern Amazonia have been in complete isolation from outside influences. As already mentioned, nonautochthonous diseases, often in epidemic form, reached native populations of the region, even those still uncontacted. As evaluated by enamel defects, the first half of this century was a stressful time period for the Tupí-M ondé. At least in part, high levels of physiological disruption in the decades preceding permanent contact may be explained as a consequence of the process of frontier expansion toward Tupí-Mondé territories, which led to a crescendo of direct and indirect stressful interactions between native peoples and the newcomers. Possibly, Tupí-M ondé groups repeatedly experienced what Posey (1987) called "contact before contact," i.e., sporadic interactions between I ndians and non-I ndians before permanent contact. F ace-to-face confrontations between Indians and nonIndians in Rondônia and Mato Grosso were reported as common during the rubber boom period in the beginning of this century as well as in the following decades. In his trip to Amazonia in the 1930s, Lévi-Strauss (1955) saw Indians with sequelae resembling poliomyelitis paralysis in what he believed to be an relatively isolated village. There are also a number of reports of epidemics and conflicts between Tupí-M ondégroups and rubber-tappers as early as in the 1940s (Brunelli, 1989; Coimbra, 1989). High DDE rates in precontact periods are likely to attest to the long-term and stressful nature of the interethnic dynamics that prevailed in the Aripuanã region in the first half of this century. This recognition leads to a rethinking of the conventional dichotomy between uncontacted "vs." contacted groups. It forces us to reconsider the simplistic notion of groups either in isolation or not, and deemphasizes the single-step concept of pristine populations becoming "acculturated" ones.

\section{CONCLUDING REMARKS}

We would like to make some final comments concerning links between this study and the broader literature on enamel defects. Whether dealing with archeological/ skeletal or living populations, studies on enamel defects within physical anthropology are often interested in "historical" issues, which might range from "developmental histories" of individuals to historical trends experienced by human societies. As an example of the first approach, one could mention those investigations that analyze enamel in order to obtain information about patterns of stress experienced by individuals. The ongoing debate about concentration of defects at certain developmental ages and its possible relation with weaning exemplifies this perspective (Blakey et al., 1994; Corruccini et al., 1985; Goodman et al., 
1987, 1991; Moggi-Cecchi et al., 1994; Wood, 1996). As for the second approach, one could refer to the paleopathological analyses that aim at characterizing health transitions in prehistory associated with transformations in social, cultural, and economic systems. Those investigations that compare health profiles of skeletal samples from different archeological time periods in a given region (Malville, 1997; Wright, 1997) and those that analyze the biological consequences of technological innovations, including intensification of agriculture (Cohen and Armelagos, 1984), are good examples of this latter approach. The vast majority of the studies concerning enamel defects fall into one of these two approaches, and sometimes into both simultaneously; they aim at gaining insights into "ontogenetic histories" of individuals and/or into "macrotemporal histories" of human societies. These perspectives greatly differ in regard to the time scale of the events they are concerned with, which might range from the few years that corre spond to the period of tooth formation to the centuries or millennia represented by skeletal samples analyzed by paleopathologists. Yet both perspectives are fundamental ly concerned with diachronicity. One might refer tothe first approach as "diachronic intraindividual" and to the second as "diachronic interpopulational."

It is our opinion that this investigation about the Tupí-Mondé helps to broaden the methodological possibilities of the already powerful analytical tool kit of hypoplasia assessment. In addition to an "intraindividual" approach, this study has utilized enamel defects in order to monitor diachronic changes within a set of culturally related Amerindian societies in a time frame that encompassed a few decades. It could be refered to as an example of a "diachronic intrapopulational" perspective.

\section{ACKNOWLEDGMENTS}

We thank P.L. J amison, E.F. Moran, and D.C. Cook for numerous constructive criticisms in earlier drafts. We also express our most sincere gratitude to A.H. Goodman, who kindly received one of the authors (R.V.S.) for a 1-week standardization training. Three anonymous reviewers posed chal- lenging questions that hel ped us to improve the paper. Fieldwork was supported by the Brazilian Research Council and the Midwest Universities Consortium for International Activities. The Brazilian Indian Foundation granted us permission to carry out the research. The authors are indebted to the Gavião, Suruí, and Zoró for their willingness to participate in this study.

\section{LITERATURE CITED}

Blakey ML, Leslie TE, Reidy J P. 1994. Frequency and chronological distribution of dental enamel hypoplasia in enslaved African Americans: a test of the weaning hypothesis. Am J Phys Anthropol 95:371383.

Brunelli G. 1989. De los espiritus a los microbios: salud y sociedad en transformación entre los Zoró de la Amazonía Brasileña. Quito: Ediciones Abya-Yala. $434 \mathrm{p}$.

Caspar F. 1957. A aculturação da tribo Tupari. Rev Antropol 5:145-171.

Chiappino J . 1975. The Brazilian indigenous problem and policy: the Aripuanã Park. Document no. 19. Copenhagen: International Work Group for Indigenous Affairs, and Geneva: Information Center for Indigenous Affairs in the Amazon Region. 28 p.

Cohen M, Armelagos GJ , editors. 1984. Paleopathology at the origins of agriculture. New York: Academic Press. $615 \mathrm{p}$.

Coimbra CEA J r. 1987. O sarampo entre sociedades indígenas brasileiras e al gumas considerações sobre a prática da saúde pública entre estas populações. Cad Saude Publica 3:22-37.

Coimbra CEA J r. 1989. From shifting cultivation to coffee farming: the impact of change on the health and ecology of the Suruí in the Brazilian Amazon. Ph.D. dissertation. Bloomington, I N: Indiana University.

Coimbra CEA J r, Mello DA. 1981. Enteroparasitoses e Capillaria sp. entre o grupo indígena Suruí, Parque Indígena Aripuanã, Rondônia. Mem Inst Oswaldo Cruz 76:299-302.

Coimbra CEA J r, Santos RV. 1991a. Parasitismo intestinal entre o grupo indígena Zoró, Estado do Mato Grosso (Brasil). Cad Saude Publica 7:100-103.

Coimbra CEA J r, Santos RV. 1991b. Avaliação do estado nutricional num contexto de mudanças sócio-econômicas: o grupo indígena Suruí do Estado de Rondônia, Brasil. Cad Saude Publica 7:538-562.

Coimbra CEA J r, Santos RV, Tanus R. 1985a. Estudos epidemiológicos entre grupos indígenas de Rondônia. I. Piodermites e portadores inaparentes de Staphylococcus sp. na boca e nariz entre os Suruí e Karitiána. Rev Inst Med Trop Sao Paulo 27:13-19.

Coimbra CEA J r, Santos RV, Tanus, R, Inham TM. 1985b. Estudos epidemiológicos entre grupos indígenas de Rondônia. II . Bactérias enteropatogênicas e gastrenterites entre os Suruí e Karitiána. Rev Fund SESP 30:111-119.

Coimbra CEA J r, Wanke B, Santos RV, ValleACF, Costa RLB, Zancopé-Oliveira RM. 1994. Paracoccidioidin and histoplasmin sensitivity in Tupí-Mondé Amerindian populations from Brazilian Amazonia. Ann Trop Med Parasitol 88:197-207.

Coimbra CEA J r, Santos RV, F lowers NM, Yoshida CFT, Baptista ML, ValleACF. 1996a. Hepatitis B epidemiology and cultural practices in Amerindian populations of Amazonia: the Tupí-Mondé and the Xavánte of Rondônia and Mato Grosso. Soc Sci Med 42:1738-1743. 
Coimbra CEA J r, Santos RV, Valle ACF. 1996b. Cutane ous leishmaniasis in Tupí-Mondé Amerindians from the Brazilian Amazonia. Acta Trop (Basel) 61:201211.

Conklin BA. 1989. Images of health, illness, and death among the Wari (Pakaas Novos) of Rondônia, Brazil. Ph.D. dissertation. Berkeley, CA: University of California.

Corruccini RS, Handler J S, J acobi KP. 1985. Chronological distribution of enamel hypoplasias and weaning in a Caribbean slave population. Hum Biol 57:699-722.

Coy M. 1987. Rondônia: frente pioneira e programa POL ONOROESTE. O processo de diferenciação sócioeconômica na periferia e os limites do planejamento político. Tubinger Geograph Stud 95:253-270.

Cutress TW, Suckling GW. 1982. The assessment of noncarious defects of enamel. I nt Dent J 32:117-122.

Davidson DM. 1970. Rivers and empire: the Madeira route and the incorporation of the Brazilian Far West. Ph.D. dissertation, Yale University (New Haven, CT).

Davis SH. 1977. Victims of the miracle. Cambridge: Cambridge University Press. 205 p.

Dennett G, Connell J . 1988. Acculturation and health in the highlands of Papua New Guinea. Curr Anthropol 29:273-299.

Downer MC, Blinkhorn AS, Holt RD, Wight C, Attwood D. 1994. Dental caries experience and defects of dental enamel among 12-year-old children in north London, Edinburgh, Glasgow and Dublin. Community Dent Oral Epidemiol 22:283-285.

Early J D, Peters J F. 1990. The population dynamics of the Mucajai Yanomama. San Diego: Academic Press. $152 \mathrm{p}$.

Enwonwu CO. 1973. Influence of socioeconomic conditions on dental development in Nigerian children. Arch Oral Biol 18:95-107.

Fédération Dentaire Internationale (FDI). 1982. An epidemiological index of developmental defects of dental enamel (DDE index). Int Dent J 32:159-167.

Goodman AH, Armelagos GJ . 1985. Factors affecting the distribution of enamel hypoplasias within the human permanent dentition. Am J Phys Anthropol 68:479493.

Goodman AH, Rose J C. 1990. Assessment of systemic physiological pertubations from dental enamel hypoplasias and associated histological structures. Yrbk Phys Anthropol 33:59-110.

Goodman AH, Rose J C. 1991. Dental enamel hypoplasias as indicators of nutritional status. In: Kelley MA, Larsen CS, editors. Advances in dental anthropology. New York: Wiley-Liss. p 279-293.

Goodman AH, Armelagos GJ , Rose J C. 1980. Enamel hypoplasias as indicators of stress in three prehistoric populations from Illinois. Hum Biol 52:515-528.

Goodman $\mathrm{AH}$, Allen LH, Hernandez GP, Amador A Arriola LV, Chávez A, Pelto GH. 1987. Prevalence and age at development of enamel hypoplasias in Mexican children. Am J Phys Anthropol 72:7-19.

Goodman AH, Martinez C, Chavez A. 1991. Nutritiona supplementation and the devel opment of linear enamel hypoplasias in children from Tezonteopan, Mexico. AmJ Clin Nutr 53:773-781.

Goodman AH, Pelto GH, Allen LH, Chavez A. 1992 Socioeconomic and anthropometric correlates of linear enamel hypoplasia in children from Solis, Mexico. Paleopathol 2:373-380.

Hemming J . 1987. Amazon frontier: the defeat of the Brazilian Indians. Cambridge: Harvard University Press. $647 \mathrm{p}$.

J ontel M, Linde A. 1986. Nutritional aspects on tooth formation. World Rev Nutr Diet 48:114-136.
King NM, Wei SHY. 1992. A review of the prevalence of developmental enamel defects in permanent teeth. J Paleopathol 2:341-357.

Kreshover S] . 1960. Metabolic disturbances in tooth formation. Ann NY Acad Sci 85:161-167.

Lanphear KM. 1990. Frequency and distribution of enamel hypoplasias in a historic skeletal sample. Am J Phys Anthropol 81:35-43.

Lévi-Strauss C. 1955. Tristes tropiques. Paris: Plon. p 399

Malville NJ. 1997. Enamel hypoplasia in ancestral Puebloan populations from Southwestern Colorado: I . Permanent dentition. Am J Phys Anthropol 102:351367

Massler M, Schour I, Poncher HG. 1941. Developmental pattern of the child as reflected in the calcification pattern of the teeth. Am J Dis Child 62:33-67.

Maunders J , Goodman A, Froment A. 1992. The ecology of dental enamel hypoplasias among seven Cameroonian groups. J Hum Ecol 2:109-116.

May RL, Goodman AH, Meindl RS. 1993. Response of bone and enamel formation to nutritional supplementation and morbidity among malnourished GuatemaIan children. AmJ Phys Anthropol 92:37-51.

Meireles DM. 1984. Populações Indígenas e a ocupação histórica de Rondônia. Cuaibá: Departamento de História, Universidade Federal de Mato Grosso. 115 p

Moggi-Cecchi J , Pacciani E, Pinto-Cisternas J . 1994. Enamel hypoplasia and age at weaning in 19thcentury Florence, Italy. Am J Phys Anthropol 93:299306

Moran EF. 1984. Colonization in the Transamazon and Rondonia. In: Schmink M, Wood CW, editors. Frontier expansion in Amazonia. Gainesville: University of Florida Press. p 285-303.

Mueller C. 1980. Frontier based agricultural expansion: the case of Rondônia. In: Barbira-Scazzocchio F, editor. Land, people and planning in contemporary Amazonia. Cambridge: Centre of Latin American Studies, University of Cambridge. p 141-153.

Neel J V, Centerwall WR, Chagnon NA, Casey HL. 1970. Notes on the effect of measles and measles vaccine in a virgin-soil population of South American Indians. Am J Epidemiol 91:418-429.

Pindborg J J . 1982. Aetiology of developmental enamel defects not related to fluorosis. I nt Dent J 32:123-134.

Posey DA. 1987. Contact before contact: typology of post-Colombian interaction with the northern Kayapó of the Amazon Basin. Bol Mus Para Emilio Goeldi 3:135-154.

Rathbun T. 1987. Health and disease in a South Carolina plantation: 1840-1870. Am J Phys Anthropol 74:239-253.

Ribeiro D. 1956. Convívio e contaminação. Efeitos dissociativos da depopulação provocada por epidemias em grupos indígenas. Sociologia 18:3-50.

Santos R. 1980. História econômica da Amazônia (18001920). São Paulo: T.A. Queirox. 358 p.

Santos RV. 1991. Coping with change in native Amazonia: a bioanthropological study of the Gavião, Suruí, and Zoró, Tupí-M ondé speaking societies from Brazil. Ph.D. dissertation. Bloomington, I N : Indiana University.

Santos RV, Coimbra CEA J r. 1991. Socioeconomictransition and physical growth of Tupí-Mondê Amerindian children of the Aripuanã Park, Brazilian Amazonia. Hum Biol 63:795-819.

Santos RV, Coimbra CEA J r. 1996. Socioeconomic differentiation and body morphology in the Surui Indians 
from the Brazilian Amazonia. Curr Anthropol 37:851856.

Santos RV, Linhares AC, Coimbra CEA J r. 1991. Estudos epidemiológicos entre grupos indígenas de Rondônia. IV. Inquérito sorológico para rotavírus entre os Suruí e Karitiána. Rev Saude Publica 25:230-232.

Sarnat BG, Schour I. 1941. Enamel hypoplasia (chronologic enamel aplasia) in relation to systemic disease: a chronologic, morphologic and etiol ogic classification. J Am Dent Assoc 28:1989-2000.

Sawyer DR, N woku AL. 1985. Malnutrition and the oral health of children in Ogbomosho, Nigeria. J Dent Child 52:141-145.

Seow WK. 1992. Dental enamel defects in low birthweight children.J Paleopathol 2:321-330.

Statistical Package for the Social Sciences (SPSS). 1992. SPSS/PC + base system user's guide. Version 5.0. Chicago: SPSS, Inc. $910 \mathrm{p}$.

Suckling GW, Pearce EIF. 1984. Devel opmental defects of enamel in a group of New Zealand children: their prevalence and some associated etiological factors. Community Dent Oral Epidemiol 12:177-184.

Sweeney EA, Cabrera J, Urrutia J, Mata L. 1969. Factors associated with linear hypoplasia of human deciduous incisors. J Dent Res 48:1275-1279.

Sweeney EA, Saffir AJ , de Leon R. 1971. Linear hypoplasia of deciduous incisor teeth in malnourished children. AmJ Clin Nutr 24:29-31.

Weinstein B. 1983. The Amazon rubber boom. Stanford: Stanford University Press. $356 \mathrm{p}$

Wirsing R. 1985. The health of traditional societies and the effects of acculturation. Curr Anthropol 26:303322.

Wood L. 1996. Frequency and chronological distribution of linear enamel hypoplasia in a North American colonial skeletal sample. Am J Phys Anthropol 100: 247-259.

Wright L . 1997. Intertooth patterns of hypoplasia expression: implications for childhood health in the classic Maya collapse. AmJ Phys Anthropol 102:233-247. 